\title{
THE ROLE OF BORON IN PREVENTION OF OSTEOARTICULAR DISEASES AND ITS DISTRIBUTION IN THE REPUBLIC OF MOLDOVA
}

\author{
Maria-Victoria RACU1 ${ }^{1}$, Ion Romulus SCOREI², Iurie PINZARU ${ }^{1}$ \\ ${ }^{1}$ National Agency for Public Health from Chisinau, Republic of Moldova \\ 2BioBoron Research Institute, Craiova, Romania
}

Corresponding author: Maria-Victoria RACU, e-mail: maria.victoria.racu@gmail.com

DOI: $10.38045 /$ ohrm.2021.4.05

CZU:

Keywords:

osteoarticular

diseases, boron,

boron com-

pounds.

Cuvinte cheie: boli osteoarticulare, bor, compuși ai borului.
Introduction. Boron is a trace mineral that is supposed to be essential for human health. Organic plant based boron compounds are highly bioavailable for humans and can positively influence minerals such as calcium, phosphorus, magnesium and act in synergy with vitamin $D$, which are beneficial for osteoarticular health.

Material and methods. We made an analysis of 126 bibliographic sources and mapped the Republic of Moldova to the content of boron in deep water and to the adults' prevalence of rheumatoid arthritis and inflammatory polyarthropathy.

Results. Boron is important for osteogenesis and its deficiency can lead to impaired growth and abnormal bones development. It supports bone health in postmenopausal women by reducing urinary loss of the minerals such as calcium, magnesium and phosphorus, which are essential for bone building. In countries where soil was depleted of boron and daily intake of this mineral was $1 \mathrm{mg}$ or lower, the incidence of arthritis was between 20 and 70\%. In Moldova, in the regions where boron concentration in deep drinking water were low $(0.28 \mathrm{mg} / \mathrm{L}$ in well water and 0.51 $\mathrm{mg} / \mathrm{L}$ in artesian well water) in Soroca in 2019, the prevalence with the rheumatoid arthritis and inflammatory polyarthropathy were high (51.6 per 10000 inhabitants) with one exception, UTA Gagauzia (35.1 per 10000 inhabitants), where we found a high boron concentration in deep drinking water $(2.05 \mathrm{mg} / \mathrm{L}$ in well water and $2.2 \mathrm{mg} / \mathrm{L}$ in artesian well water) in 2015.

Conclusions. Boron can affect bone metabolism. In regions where boron concentration in deep drinking water is low, the osteoarticular morbidity can be higher with the exception of UTA Gagauzia, where we suppose that dietary pattern can be a cause of these results. In the future we will study eating habits in this region and a clearer conclusion will be made.

\section{ROLUL BORULUI ÎN PREVENIREA BOLILOR OSTEOARTICULARE ȘI DISTRIBUTIA ACESTUIA PE TERITORIUL REPUBLICII MOLDOVA}

Introducere. Borul este un microelement probabil esențial pentru oameni. Compușii organici ai borului au o biodisponibilitate înaltă pentru oameni și pot influența pozitiv metabolismul calciului, fosforului și al magneziului, acționând în sinergie cu vitamina $D$, în mod pozitiv pentru oase.

Material și metode. Pentru realizarea studiului au fost analizate 126 de surse bibliografice, a fost cartografiată Republica Moldova după concentrația borului în apa potabilă de profunzime și după prevalența adulților prin artrită reumatoidă și poliartropatiile inflamatorii.

Rezultate. Borul este important pentru osteogeneză, iar deficiența acestuia poate compromite creșterea și dezvoltarea oaselor. El susține sănătatea osoasă a femeilor aflate în menopauză prin reducerea pierderii urinare a calciului, magneziului și a fosforului. În țările în care solul este privat de bor, iar aportul zilnic al acestui mineral este de $1 \mathrm{mg}$ și mai puțin, incidența artritei este cuprinsă între 20 și 70\%. În Moldova, în regiunile în care concentrația borului în apa potabilă de profunzime a fost joasă $(0,28 \mathrm{mg} / \mathrm{l}$ în apa din fântâni și 0,51 $\mathrm{mg} / \mathrm{l}$ în apa din sondele arteziene în Soroca în 2019), prevalența prin artrită reumatoidă și poliartropatii inflamatorii a fost înaltă (51,6 pentru 10000 locuitori), cu o singură excepție - UTA Găgăuzia (35,1 pentru 10 000 locuitori), unde am depistat o concentrație înaltă a borului în apa potabilă de profunzime (2,05 mg/l în apa din fântâni și 2,2 mg/l în apa din sondele arteziene) în anul 2015.

Concluzii. Borul poate afecta metabolismul osos. În regiunile în care concentrația borului în apa potabilă de profunzime este joasă, morbiditatea osteoarticulară poate fi înaltă, cu excepția UTA Gagauzia, unde presupunem că deprinderile alimentare ale locuitorilor pot cauza aceste rezultate. Astfel, modul de alimentație al locuitorilor din această zonă se impune a fi studiat în profunzime și doar atunci vom putea trasa concluzii mai clare. 


\section{INTRODUCTION}

Boron is a trace mineral that is supposed to be essential for human health. It can enter the body from two main sources: fruits and vegetables in organics form and water in an inorganic form. From all known compounds, the organic, plantbased ones are highly bioavailable for humans and can positively influence minerals such as calcium, phosphorus, magnesium and act in synergy with vitamin $D$, which are known to be beneficial for osteoarticular health. From scientific evidence we know that boron can positively influence the symptoms and prevent osteoarticular diseases such as osteoarthritis, rheumatoid arthritis and osteoporosis. In countries where soil was depleted of boron and daily intake of this mineral was $1 \mathrm{mg}$ or lower, the incidence of arthritis was very high. We suppose that in the Republic of Moldova can be areas were soil and drinking water is depleted of boron and it may be necessary to study osteoarticular diseases in those regions in the future.

The aim of this study was to determine the role of boron in prevention of osteoarticular diseases from the literature and the possible relationship between the concentration of boron in deep drinking water and the prevalence of rheumatoid arthritis and inflammatory polyarthropathy in 2015-2019 periods in the Republic of Moldova.

\section{MATERIAL AND METHODS}

We made a literature review of 126 bibliographic sources that highlighted the boron and its compounds functions and their role in prevention of osteoarticular diseases. We searched the electronic database MEDLINE (PubMed, https:// pubmed.ncbi.nlm.nih.gov/), Google Scholar (https://scholar.google.com/), ProQuest (https: //www.proquest.com/), Scopus (https://www. scopus.com/) until June 2021, using the following key terms: "boron", "boron compounds", "organic boron compounds" combined using the Boolean operator AND "osteoarticular diseases", "rheumatoid arthritis", "osteoarthritis". The reference list from the resulting publications was manually searched for any relevant trials with elimination of results not related to the article topic. The resulting list of publications was limited to include only English.

Also, we collected data on boron concentration in deep water (wells and artesian wells) from different regional public health centers of the Republic of Moldova for the 2015-2019 period, analyzed them and put the average concentrations on the map of the country. For data analysis was used Microsoft Excel 2010 and for maps - the soft Datawrapper (https://app.datawrap per.de/)

Boron concentration in deep drinking water was determined in regional public health centers using the photocolorimetric method and the ability of boric acid to change the color of carmine in the presence of concentrated sulfuric acid from red to purple-blue as a result of the formation of the boric acid ether complex. The performance features of the method are set in $0.1-1.0 \mathrm{mg} / \mathrm{L}$ range.

We classified boron concentration in deep drinking water as following: low $(0-0.8 \mathrm{mg} / \mathrm{L})$, medium (0.9-1.2 mg/L) and high $(1.2 \mathrm{mg} / \mathrm{L}$ and more). After this, in order to establish a possible connection between boron concentration in deep drinking water and the prevalence with rheumatoid arthritis and inflammatory polyarthropathy of the population, we collected data on population morbidity with these diseases from the Health Data Management Department of the National Agency for Public Health. After that, we mapped the Republic of Moldova of the prevalence with rheumatoid arthritis and inflammatory polyarthropathy for 2016 and 2019 years using the same soft - Datawrapper.

The data obtained will be used in an ecological descriptive epidemiological study in which we will describe the correlation between boron concentration in deep drinking water and the population morbidity with rheumatoid arthritis and osteoarthritis.

\section{RESULTS}

The reviewed literature highlights the essential of boron in the normal development of the skeleton, maintenance of bone health throughout life and beneficially influences minerals such as calcium magnesium, and vitamin D (1).

It appears that boron can be primarily found in soil and in deep drinking water in an inorganic form. Then it's processed by plants and microorganisms and is transformed into organic compounds, known as boron containing compounds 
(BCC) that is highly available for human body (2).

Thus, the main sources of boron in organic form are fruits and vegetables and in an inorganic form drinking water (especially deep water, in which there is no human impact) (3).

Comparing these two sources, on average, vegetable foods can supply human body with $1.0 \mathrm{mg}$ of B per day and drinking water with $0,6 \mathrm{mg}$ of $\mathrm{B}$ per day (3). We should mention that this amount will vary depending on the region and the boron concentration in rocks and respectively, in deep water.

Studying boron intake from deep drinking water

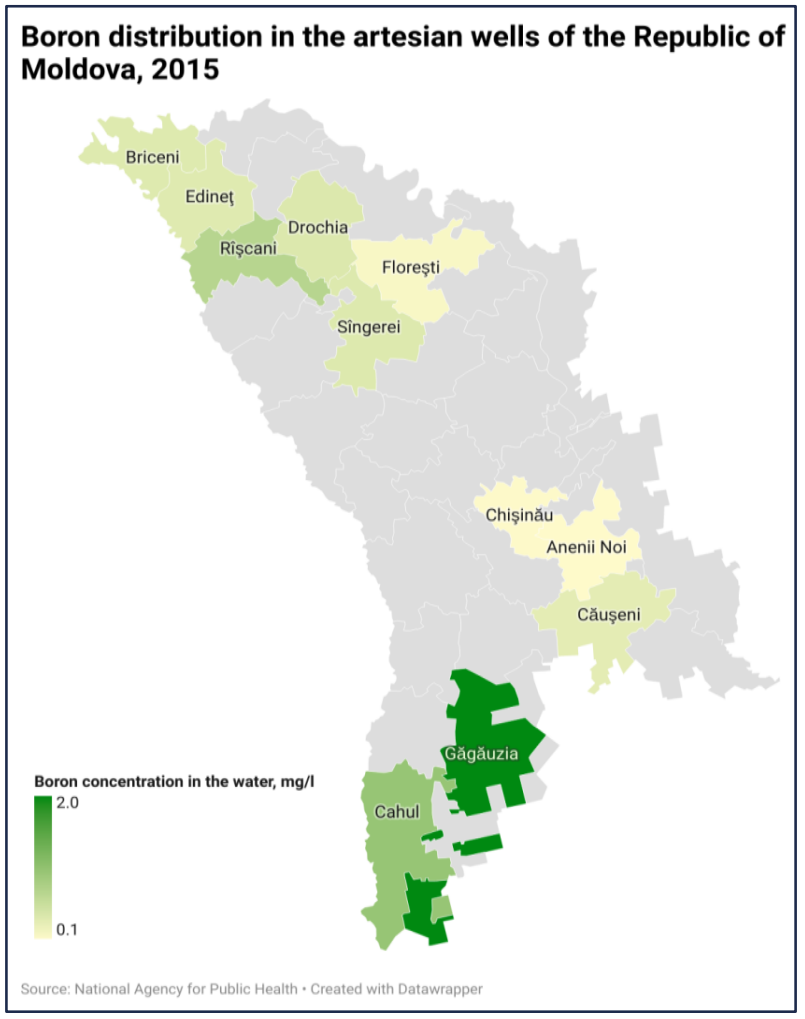

Figure 1. Boron distribution in the artesian wells of the Republic of Moldova, 2015.

Following the map, in 2015, the highest concentration of boron in artesian well was detected in UTA Gagauzia (2.2 mg/L average concentration) and the lowest in Anenii Noi $(0.08 \mathrm{mg} / \mathrm{L})$.

Boron concentrations from other regions on the map are listed in the Table 1.

For 2019, also, the highest boron concentration in drinking water from artesian well was detect- is an accessible method for the Republic of Moldova, where the water samples are collected and analyzed by the local public health centers and data are sent to the National Agency for Public Health. We chose to study this important boron source because there is no available method of studying boron concentration in fruits and vegetables in the Republic of Moldova.

From 2015 to 2019 number of regions from where deep water samples were collected and analyzed in the environmental hygiene laboratories has increased from 11 (fig.1) to 26 (fig. 2) for artesian wells and from 8 (fig. 3) to 9 for wells (fig. 4).

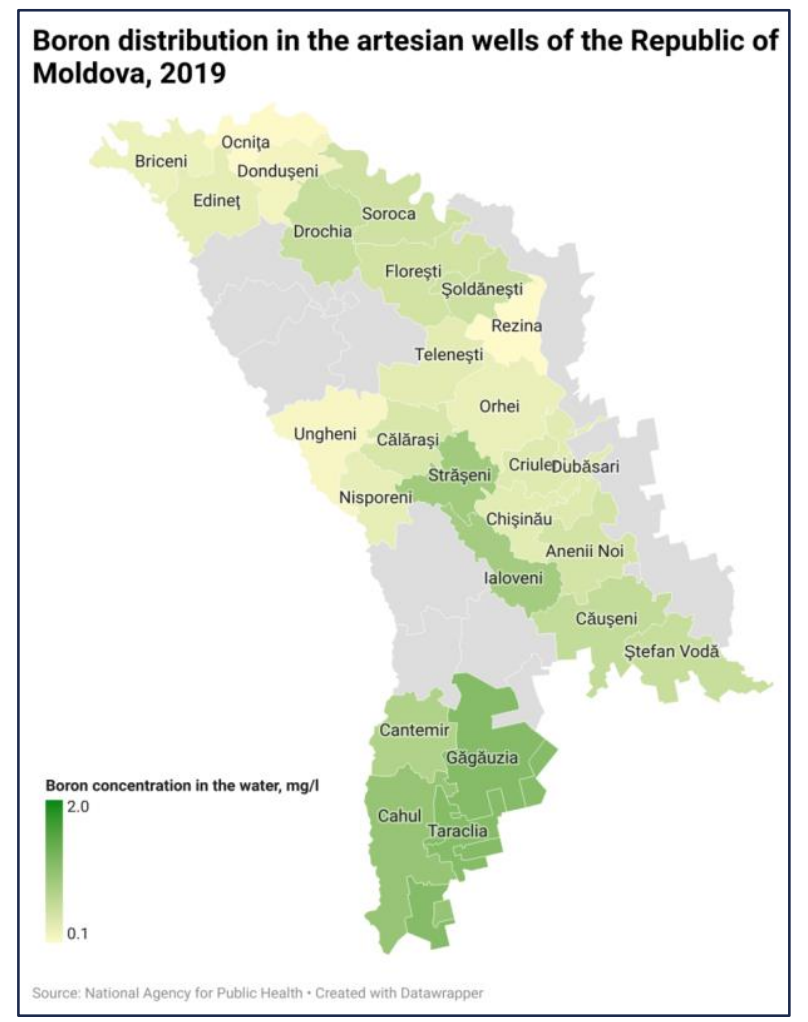

Figure 2. Boron distribution in the artesian wells of the Republic of Moldova, 2019.

ed in UTA Gagauzia, in the south region of the Republic of Moldova (1.15 mg/L) and the lowest in the north part - Ocnita $(0.11 \mathrm{mg} / \mathrm{L})$.

In other regions of the Republic of Moldova were found boron concentrations that are between these two values (tab.2). 
Table 1. Average boron concentration in the artesian well water from different region of the Republic of Moldova, 2015.

\begin{tabular}{clc}
\hline Number & Region of the Republic of Moldova & $\begin{array}{c}\text { Average boron concentration in } \\
\text { the region, } \mathbf{~ m g} / \mathbf{L}\end{array}$ \\
\hline $\mathbf{1 .}$ & Cahul & 1.0 \\
\hline $\mathbf{2 .}$ & Causeni & 0.33 \\
\hline $\mathbf{3 .}$ & UTA Gagauzia & 2.2 \\
\hline $\mathbf{4 .}$ & Anenii Noi & 0.08 \\
\hline $\mathbf{5 .}$ & Chisinau & 0.11 \\
\hline $\mathbf{6 .}$ & Briceni & 0.38 \\
\hline $\mathbf{7 .}$ & Edineț & 0.37 \\
\hline $\mathbf{8 .}$ & Riscani & 0.72 \\
\hline $\mathbf{9 .}$ & Singerei & 0.39 \\
\hline $\mathbf{1 0 .}$ & Drochia & 0.4 \\
\hline $\mathbf{1 1 .}$ & Floresti & 0.15 \\
\hline
\end{tabular}

Table 2. Average boron concentration in the artesian well water from different region of the Republic of Moldova, 2019.

\begin{tabular}{clc}
\hline Number & \multicolumn{1}{c}{ Region of the Republic of Moldova } & $\begin{array}{c}\text { Average boron concentration in the } \\
\text { region, } \mathbf{~ m g} / \mathbf{L}\end{array}$ \\
\hline $\mathbf{1 .}$ & Cahul & 1.0 \\
\hline $\mathbf{2 .}$ & Cantemir & 0.78 \\
\hline $\mathbf{3 .}$ & UTA Gagauzia & 1.15 \\
\hline $\mathbf{4 .}$ & Ocnita & 0.11 \\
\hline $\mathbf{5 .}$ & Causeni & 0.61 \\
\hline $\mathbf{6 .}$ & Stefan Voda & 0.57 \\
\hline $\mathbf{7 .}$ & Dubasari & 0.35 \\
\hline $\mathbf{8 .}$ & Taraclia & 1.14 \\
\hline $\mathbf{9 .}$ & Anenii Noi & 0.47 \\
\hline $\mathbf{1 0 .}$ & Calarasi & 0.42 \\
\hline $\mathbf{1 1 .}$ & Chisinau & 0.34 \\
\hline $\mathbf{1 2 .}$ & Criuleni & 0.38 \\
\hline $\mathbf{1 3 .}$ & Ialoveni & 0.88 \\
\hline $\mathbf{1 4 .}$ & Orhei & 0.27 \\
\hline $\mathbf{1 5 .}$ & Straseni & 0.9 \\
\hline $\mathbf{1 6 .}$ & Nisporeni & 0.3 \\
\hline $\mathbf{1 7 .}$ & Ungheni & 0.16 \\
\hline $\mathbf{1 8 .}$ & Briceni & 0.25 \\
\hline $\mathbf{1 9 .}$ & Donduseni & 0.2 \\
\hline $\mathbf{2 0 .}$ & Edinet & 0.31 \\
\hline $\mathbf{2 1 .}$ & Soldanesti & 0.52 \\
\hline $\mathbf{2 2 .}$ & Drochia & 0.57 \\
\hline $\mathbf{2 3 .}$ & Soroca & 0.51 \\
\hline $\mathbf{2 4 .}$ & Floresti & 0.49 \\
\hline $\mathbf{2 5 .}$ & Rezina & 0.1 \\
\hline $\mathbf{2 6 .}$ & Telenesti & 0.33 \\
\hline & & \\
\hline
\end{tabular}

In the well drinking water from UTA Gagauzia situated in the south part of the Republic of Moldova was recorded the highest level of boron -
$2.05 \mathrm{mg} / \mathrm{L}$ in 2015 . The lowest level was detected in the central part, Anenii Noi $-0.04 \mathrm{mg} / \mathrm{L}$.

All the concentration of boron in well drinking water can be seen in the Table 3 . 


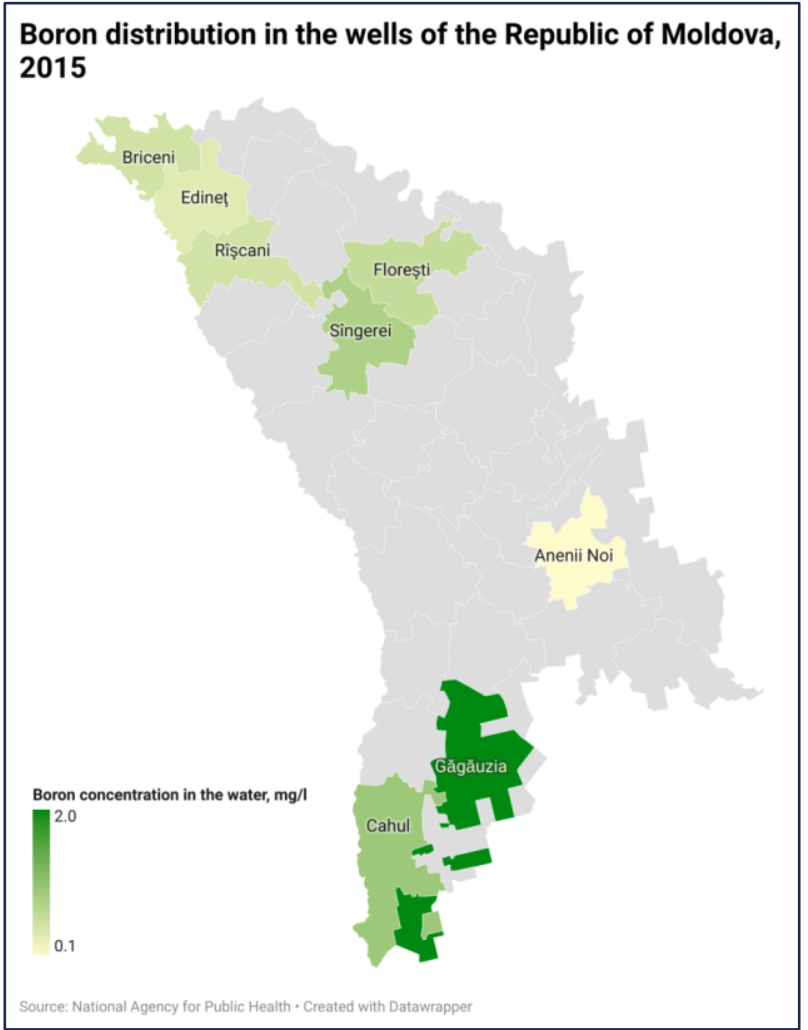

Figure 3. Boron distribution in the wells of the Republic of Moldova, 2015.

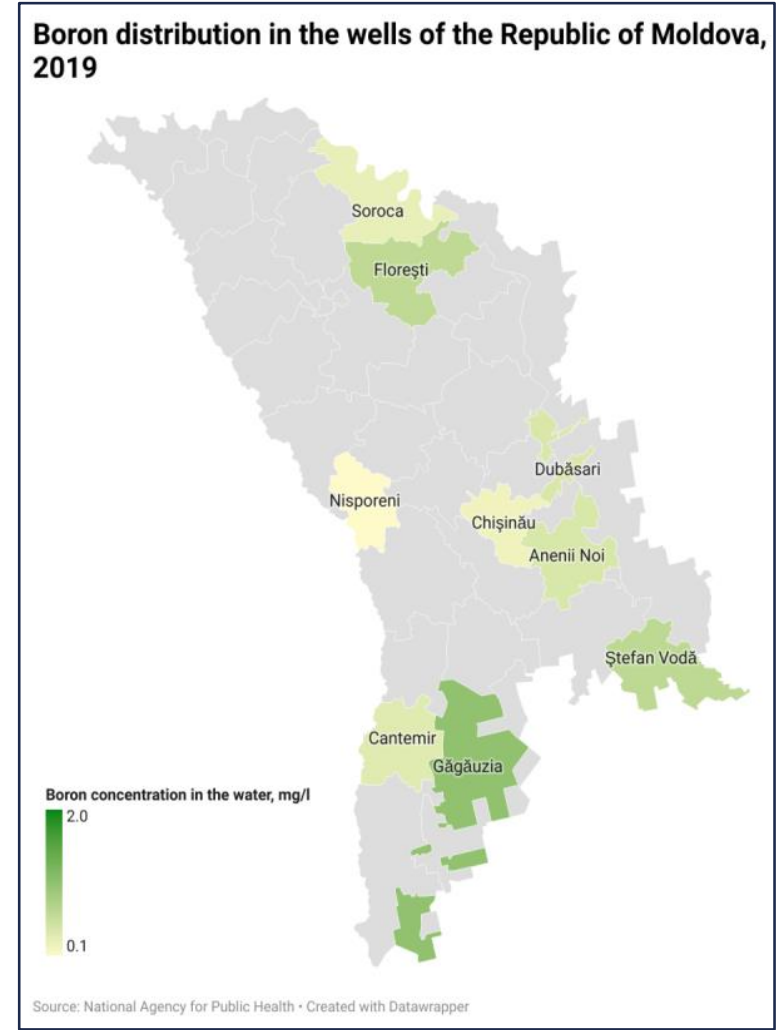

Figure 4. Boron distribution in the wells of the Republic of Moldova, 2019.

Table 3. Average boron concentration in the well water from different region of the Republic of Moldova, 2015.

\begin{tabular}{llc}
\hline Number & \multicolumn{1}{c}{ Region of the Republic of Moldova } & $\begin{array}{c}\text { Average boron concentration in the re- } \\
\text { gion, } \mathbf{~ m g / L}\end{array}$ \\
\hline $\mathbf{1 .}$ & Cahul & 0.95 \\
\hline $\mathbf{2 .}$ & Briceni & 0.5 \\
\hline $\mathbf{3 .}$ & UTA Gagauzia & 2.05 \\
\hline $\mathbf{4 .}$ & Anenii Noi & 0.04 \\
\hline $\mathbf{5 .}$ & Edineț & 0.36 \\
\hline $\mathbf{6 .}$ & Riscani & 0.5 \\
\hline $\mathbf{7 .}$ & Singerei & 0.8 \\
\hline $\mathbf{8 .}$ & Floresti & 0.61 \\
\hline
\end{tabular}

For 2019, the highest boron concentration in well drinking water was recorded in UTA Gagauzia $(1.05 \mathrm{mg} / \mathrm{L})$ and the lowest in the central part of the country, in Nisporeni $(0.1 \mathrm{mg} / \mathrm{L})$.

All the boron concentrations in well water for 2019 can be followed in the Table 4 .

The data presented above highlighted the regions of the Republic of Moldova with the low and high boron in the soil, the drinking water and in the fruits and vegetables consumed by the population. Also, this suggests that in the area with the lowest boron concentration population can be more affected by the osteoarticular diseases.

In order to check this possible connection, we mapped adults' prevalence with rheumatoid arthritis and inflammatory polyarthropathy for 2016 and 2019 years.

In the map we used all available data on the adults' prevalence, because we expect in the future next years to collect data of boron containing in deep drinking water from all the regions of the Republic of Moldova. 
Table 4. Average boron concentration in the well water from different region of the Republic of Moldova, 2019.

\begin{tabular}{llc}
\hline Number & \multicolumn{1}{c}{ Region of the Republic of Moldova } & $\begin{array}{c}\text { Average boron concentration in the region, } \\
\mathbf{m g} / \mathbf{L}\end{array}$ \\
\hline $\mathbf{1 .}$ & Cantemir & 0.36 \\
\hline $\mathbf{2 .}$ & Stefan Voda & 0.66 \\
\hline $\mathbf{3 .}$ & UTA Gagauzia & 1.05 \\
\hline $\mathbf{4 .}$ & Nisporeni & 0.1 \\
\hline $\mathbf{5 .}$ & Anenii Noi & 0.43 \\
\hline $\mathbf{6 .}$ & Chisinau & 0.22 \\
\hline $\mathbf{7 .}$ & Dubasari & 0.42 \\
\hline $\mathbf{8 .}$ & Soroca & 0.28 \\
\hline $\mathbf{9 .}$ & Floresti & 0.64 \\
\hline
\end{tabular}

Adults prevalence with rheumatoid arthritis and

inflammatory polyarthropathy, 2016

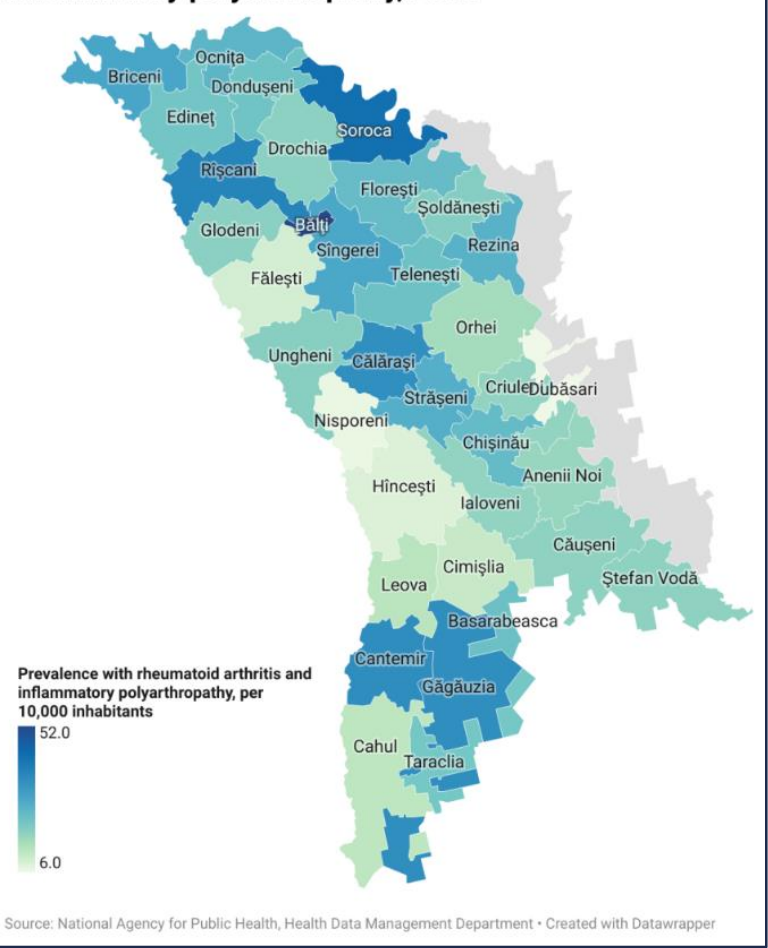

Figure 5. Adults' prevalence with rheumatoid arthritis and inflammatory polyarthropathy in the Republic of Moldova, 2016.

In the following table we will present adults prevalence with rheumatoid arthritis and inflammatory polyarthropathy in the regions were boron concentrations in deep drinking water are known. Following this we will be able to suppose if there is a connection between boron concentration in deep drinking water and population morbidity with rheumatoid arthritis and inflammatory polyarthropathy.

For the regions where boron concentration in
Adults prevalence with rheumatoid arthritis and

inflammatory polyarthropathy, 2019

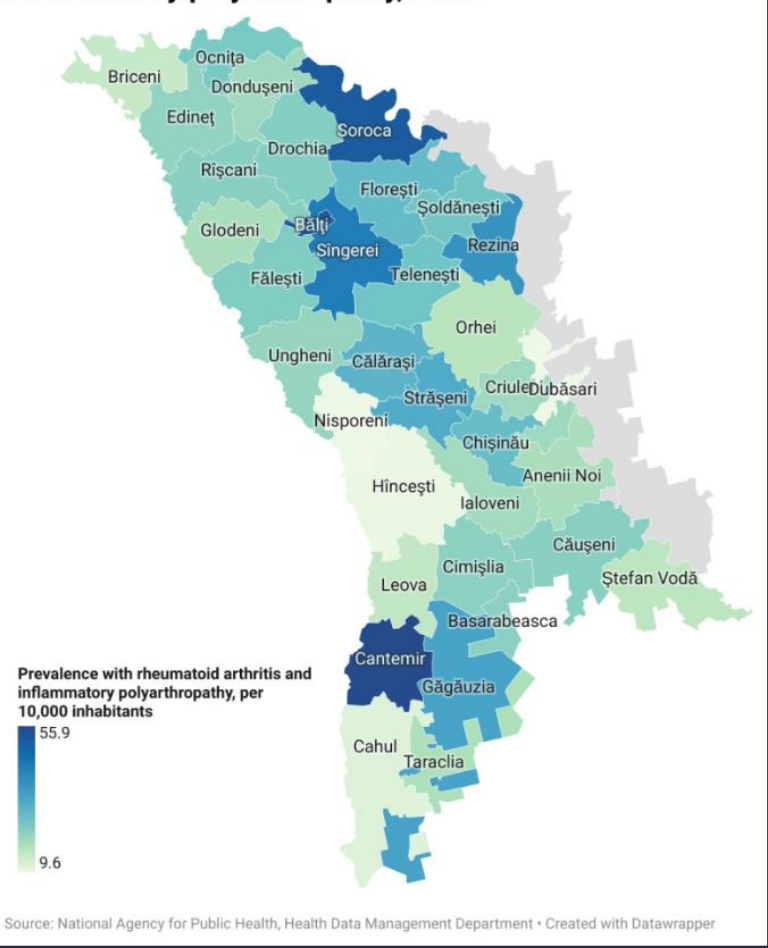

Figure 6. Adults' prevalence with rheumatoid arthritis and inflammatory polyarthropathy in the Republic of Moldova, 2019.

deep drinking water is known, in 2016, the highest prevalence with rheumatoid arthritis and inflammatory polyarthropathy were found in UTA Gagauzia (35.1 per 10000 inhabitants) and in Briceni (29.4 per 10000 inhabitants).

In these regions we found a high boron concentration in UTA Gagauzia $(2.05 \mathrm{mg} / \mathrm{L}$ in well water and $2.2 \mathrm{mg} / \mathrm{L}$ in artesian well water), but a low one in Briceni $(0.5 \mathrm{mg} / \mathrm{L}$ in well water and $0.38 \mathrm{mg} / \mathrm{L}$ in artesian well water). 
Table 5. Adults' prevalence with rheumatoid arthritis and inflammatory polyarthropathy from different region of the Republic of Moldova, 2016.

\begin{tabular}{llc}
\hline Number & Region of the Republic of Moldova & $\begin{array}{c}\text { Prevalence with rheumatoid arthritis and } \\
\text { inflammatory polyarthropathy, per 10000 } \\
\text { inhabitants }\end{array}$ \\
\hline $\mathbf{1 .}$ & Cahul & 12.6 \\
\hline $\mathbf{2 .}$ & Briceni & 29.4 \\
\hline $\mathbf{3 .}$ & UTA Gagauzia & 35.1 \\
\hline $\mathbf{4 .}$ & Anenii Noi & 17.4 \\
\hline $\mathbf{5 .}$ & Edinet & 21.7 \\
\hline $\mathbf{6 .}$ & Riscani & 37.6 \\
\hline $\mathbf{7 .}$ & Singerei & 29.1 \\
\hline $\mathbf{8 .}$ & Floresti & 24.1 \\
\hline $\mathbf{9 .}$ & Chisinău & 24.5 \\
\hline $\mathbf{1 0 .}$ & Căuseni & 18.5 \\
\hline $\mathbf{1 1 .}$ & Drochia & 18.7 \\
\hline
\end{tabular}

The situation in UTA Gagauzia, where both prevalence with rheumatoid arthritis and inflammatory polyarthropathy (35.1 per 10000 inhabitants) and boron concentration in deep drinking water $(2.05 \mathrm{mg} / \mathrm{L}$ in well water and $2.2 \mathrm{mg} / \mathrm{L}$ in artesian well water) are high, is one that indicates to the exception from the working theory. We suppose that the cause can be the dietary pattern of the population in this region and people consume less fruits and vegetables, the main sources of boron containing compounds for the human body. We will check this theory during the ecological descriptive epidemiological study in this region where we will study the dietary patterns and will make a clearer conclusion.

We will note that the highest prevalence with rheumatoid arthritis and inflammatory polyarthropathy in 2016, from all Republic was recorded in Bălți (52.0 per 10000 inhabitants), but we do not have the boron concentration from this region, neither for 2015, nor for 2019. This will be a goal to achieve during the next years.

In Cahul, where the lowest prevalence of the diseases was recorded (12.6 per 10000 inhabitants), boron concentration in deep drinking water is at medium level $(0.95 \mathrm{mg} / \mathrm{L}$ in well water and $1.0 \mathrm{mg} / \mathrm{L}$ in artesian well water).

Following the Figure 1 and Figure 3, in the region with the highest boron concentration, UTA Gagauzia $(2.05 \mathrm{mg} / \mathrm{L}$ in well water and $2.2 \mathrm{mg} / \mathrm{L}$ in artesian well water), the prevalence with rheumatoid arthritis and inflammatory polyarthropathy were high in 2016 (35.1 per 10000 inhabitants). In the region were the lowest boron concentration was recorded, in Anenii Noi $(0.04$ $\mathrm{mg} / \mathrm{L}$ in well water and $0.08 \mathrm{mg} / \mathrm{L}$ in artesian well water), the prevalence of these diseases was medium in 2016 (17.4 per 10000 inhabitants).

Also, we mapped the Republic of Moldova with adults' prevalence with rheumatoid arthritis and inflammatory polyarthropathy for 2019 year.

Also, we put in the following table the prevalence with rheumatoid arthritis and inflammatory polyarthropathy for the regions in where we know the boron concentrations in the deep drinking water.

For the regions where boron concentration in deep drinking water is known, in 2019, the highest prevalence with rheumatoid arthritis and inflammatory polyarthropathy were found in Cantemir (55.9 per 10000 inhabitants) and in Soroca (51.6 per 10000 inhabitants).

In these regions we found a low boron concentration both in Cantemir (0.36 in well water and 0.78 in artesian well water) and in Soroca (0.28 in well water and 0.51 in artesian well water).

Following the table 6, the lowest prevalence with rheumatoid arthritis and inflammatory polyarthropathy were recorded in Dubăsari (9.6 per 10000 inhabitants), where the boron concentration is at low level (0.42 in well water and 0.35 in artesian well water).

Following the Figure 2 and Figure 4, in the region with the highest boron concentration, UTA Gagauzia ( $1.05 \mathrm{mg} / \mathrm{L}$ in well water and 1.15 $\mathrm{mg} / \mathrm{L}$ in artesian well water), the prevalence 
with rheumatoid arthritis and inflammatory polyarthropathy in 2019 were high (33.7 per 10000 inhabitants). The same as for 2016 year, we suppose that the dietary pattern of the population can be a cause of this results, because not only the drinking water is the dietary source of boron for the human body.
In the regions where boron concentration in deep drinking water were low, Nisporeni 0.1 $\mathrm{mg} / \mathrm{L}$ in well water) and Ocnita $(0.11 \mathrm{mg} / \mathrm{L}$ in artesian well water), the prevalence with these diseases was low in Nisporeni (10.0 per 10000 inhabitants) and medium in Ocnita (24.6 per 10000 inhabitants).

Table 6. Adults' prevalence with rheumatoid arthritis and inflammatory polyarthropathy from different region of the Republic of Moldova, 2019.

\begin{tabular}{llc}
\hline Number & \multicolumn{1}{c}{ Region of the Republic of Moldova } & $\begin{array}{c}\text { Prevalence with rheumatoid arthritis and } \\
\text { inflammatory polyarthropathy, per 10000 } \\
\text { inhabitants }\end{array}$ \\
\hline $\mathbf{1 .}$ & Cahul & 12.0 \\
\hline $\mathbf{2 .}$ & Cantemir & 55.9 \\
\hline $\mathbf{3 .}$ & UTA Gagauzia & 33.7 \\
\hline $\mathbf{4 .}$ & Ocnita & 24.5 \\
\hline $\mathbf{5 .}$ & Causeni & 22.9 \\
\hline $\mathbf{6 .}$ & Stefan Voda & 16.4 \\
\hline $\mathbf{7 .}$ & Dubasari & 9.6 \\
\hline $\mathbf{8 .}$ & Taraclia & 18.2 \\
\hline $\mathbf{9 .}$ & Anenii Noi & 18.8 \\
\hline $\mathbf{1 0 .}$ & Calarasi & 29.7 \\
\hline $\mathbf{1 1 .}$ & Chisinau & 27.7 \\
\hline $\mathbf{1 2 .}$ & Criuleni & 20.3 \\
\hline $\mathbf{1 3 .}$ & Ialoveni & 19.6 \\
\hline $\mathbf{1 4 .}$ & Orhei & 16.9 \\
\hline $\mathbf{1 5 .}$ & Straseni & 31.8 \\
\hline $\mathbf{1 6 .}$ & Nisporeni & 10.0 \\
\hline $\mathbf{1 7 .}$ & Ungheni & 21.2 \\
\hline $\mathbf{1 8 .}$ & Briceni & 15.2 \\
\hline $\mathbf{1 9 .}$ & Donduseni & 20.1 \\
\hline $\mathbf{2 0 .}$ & Edinet & 21.8 \\
\hline $\mathbf{2 1 .}$ & Soldanesti & 25.4 \\
\hline $\mathbf{2 2 .}$ & Drochia & 23.4 \\
\hline $\mathbf{2 3 .}$ & Soroca & 51.6 \\
\hline $\mathbf{2 4 .}$ & Floresti & 28.2 \\
\hline $\mathbf{2 5 .}$ & Rezina & 37.7 \\
\hline $\mathbf{2 6 .}$ & Telenesti & 25.8 \\
\hline & & \\
\hline
\end{tabular}

\section{DISCUSSIONS}

From the reviewed literature we know that boron (B) is supposed to be probable essential for human health (2).

From all known compounds, plant-based organic BCC such as sugars and polyalcohol borate esters are very important in human nutrition. They are highly bioavailable for humans and can be used in cell metabolism during which they are at least partially transformed into boric acid (BA) that will subsequently be eliminated as waste (2). It has been known for a long time that B deficiency in soils, leads to depletion of BCCs in fruits and vegetables in the food supply, was correlated with a high incidence of arthritis (2).

Recently published research reported that people older than 40 years of age can prevent and/or correct arthritis, osteoporosis and osteoarthritis by taking $\mathrm{B}$ equal to or higher than 3 $\mathrm{mg}$ /day (3).

Although there is evidence from the countries discussed, the global scientific community has no yet accepted that B is an important micronutrient for human nutrition and its important role in human metabolism; however, we hope that in a short term the B essentiality for human will be 
proven (3).

To date, the most studied BCC is calcium fructoborate, which benefits were demonstrated by significant reductions in knee discomfort and improved flexibility of patients with osteoarthritis $(4,5)$.

The primary dietary sources of BCC are dried fruits, nuts (almonds) and avocados that contain between 1 and $4.5 \mathrm{mg}$ of boron/100 g. Fresh fruits, vegetables (especially apples, grape, broccoli, bananas, plum, peach, pomegranate and tomato, celery), and honey, contains between 0.1 to $0.5 \mathrm{mg}$ boron $/ 100 \mathrm{~g}$, whereas animal foods provide only 0.01 to $0.06 \mathrm{mg}$ of boron/100 g. Another important source of boron, in an inorganic form, is water, and the content varies according to geographic location (6).

Also, boron deficiency leads to impaired growth and abnormal bone development $(7,8)$. With 3 $\mathrm{mg} /$ day of boron supplementation the women's daily urinary excretion of calcium can be reduced by $44 \%$ (8).

Boron also beneficially impacts vitamin-D utilization. Supplementation with boron stimulates bone growth in vitamin-D deficient animals and alleviates dysfunctions in mineral metabolism characteristic of vitamin-D deficiency (8).

R. E. Newnham investigated the incidence of arthritis in various areas of the world where boron in the soil and water was considerably above or below the normal level. According to his findings in the region were estimated intake of boron was less than $1 \mathrm{mg}$ per day (Jamaica and Mauritius) the arthritis incidence was between 50 and $70 \%$. Opposite this, in the area were boron intake was 6 to 10 and more mg per day (Australia, Israel and New Zealand) the arthritis incidence was between $1 \%$ and none $(9,10)$.

According to our findings, in 2016, in Briceni, the region of the Republic of Moldova where the prevalence with the rheumatoid arthritis and inflammatory polyarthropathy were high (29.4 per 10000 inhabitants) (fig. 5, tab. 5), the boron concentration in deep drinking water were low in $2015(0.5 \mathrm{mg} / \mathrm{L}$ in well water and $0.38 \mathrm{mg} / \mathrm{L}$ in artesian well water). (fig. 1, 3, tab. 1, 3)

The same reverse connection we found in 2019, when the highest prevalence with the rheumatoid arthritis and inflammatory polyarthropathy were in the regions Cantemir (55.9 per 10000 inhabitants) and Soroca (51.6 per 10000 inhabitants) (fig. 6, tab. 6), with a low level of boron in deep drinking water recorded the same year, 0.36 in well water and 0.78 in artesian well water in Cantemir and 0.28 in well water and 0.51 in artesian well water in Soroca. (fig. 2, 4, tab. 2, 4)

These findings can support the theory described above and the connection between a lower concentration of $\mathrm{B}$ in deep drinking water and a higher morbidity with the rheumatoid arthritis and inflammatory polyarthropathy and vice versa can exist.

Studies on animals demonstrate that the changes in bone structure and formation induced by boron deprivation apparently affect bone strength and could increase the risk of osteoporosis. Calcium fructoborate incorporated into margarine was found to improve bone density in 66 of 100 patients with osteoporosis. As a result, it was concluded that calcium fructoborate could be a good adjuvant in the treatment of osteoporosis (11).

Since 1980 it is considered that boron play a role in regulating mineral metabolism (such as calcium and magnesium) and enhancing the vitamin D activation process in humans. (12)

So far, over 20 reports have appeared indicating that boron can beneficially affect bone growth and maintenance (13).

It's supposed that this mineral is required for normal bone metabolism that can lead to hypothesis of using boron both in the prevention of osteoporosis and in the treatment of osteoarthritis (14). Boron supports bone health in postmenopausal women, reducing the urinary loss of the minerals calcium, magnesium, and phosphorus, which are essential for bone-building (15).

Lower serum levels of boron have been shown in individuals with both rheumatoid arthritis (RA) and osteoarthritis $(\mathrm{OA})(16,17)$. In patients with RA is recorded a significant lower serum boron level when comparing to patients without RA. Rheumatoid factor titer is significant predictor of low serum boron level (18). This may suggest that boron element may play a role in pathophysiology of RA, OA and its severity. Supplementation with boron element and diets rich in fruits, vegetables, nuts, and pulses may be useful (19). 
According to one study, femoral OA bone contains less boron, than does normal bone, suggesting that boron might have a beneficial effect in OA (20).

The supplementation as calcium fructoborate (6 mg per day) can alleviate pain, joint rigidity and increase the mobility of the patients $(21,22)$.

Following the USA Nutritional Protocol for Osteoarthritis (Degenerative Joint Disease), it is recommended a supplementation of $6 \mathrm{mg}$ of boron per day for patients with osteoarthritis (23).

According to boron concentrations collected from deep water from the Republic of Moldova and the adults' prevalence with the rheumatoid arthritis and inflammatory polyarthropathy, we suspect the association between low concentration of boron in deep drinking water (0-0.8 $\mathrm{mg} / \mathrm{L}$ ) and a high prevalence with osteoarticular diseases.

According other studies, the population from area with a low boron concentration in deep drinking water may need an additional boron supplementation. Following these, we are going to analyze in details the population osteoarticular morbidity (osteoarthritis and rheumatoid arthritis) in the region of the Republic of Moldova with low and high boron concentration in the deep water in order to recommend an additional boron supplemen-tation for the population from depleted of boron regions.

\section{CONCLUSIONS}

1. Boron can affect bone metabolism through regulating mineral metabolism (such as calcium and magnesium) and enhancing the vitamin D activation process in humans.

2. An inadequate intake of less than $3 \mathrm{mg}$ of boron per day can worsen the symptoms of rheumatoid arthritis, osteoarthritis or osteoporosis.

3. In the regions of the Republic of Moldova where boron concentration in deep drinking water is low $(0.5 \mathrm{mg} / \mathrm{L}$ in well water and $0.38 \mathrm{mg} / \mathrm{L}$ in artesian well water) in Briceni, in 2015 and (0.28 in well water and 0.51 in artesian well water) in Soroca in 2019, the prevalence with the rheumatoid arthritis and inflammatory polyarthropathy were high (29.4 per 10000 inhabitants) in Briceni in 2016 and the same (51.6 per 10000 inhabitants) in Soroca in 2019.

4. The only major exception from the working theory is UTA Gagauzia region, where we found a high boron concentration in deep drinking water in $2015(2.05 \mathrm{mg} / \mathrm{L}$ in well water and 2.2 $\mathrm{mg} / \mathrm{L}$ in artesian well water) and a high prevalence with the rheumatoid arthritis and inflammatory polyarthropathy (35.1 per 10000 inhabitants) in 2016. For this region we don't have a clear scientific explanation, but we suppose that it can be caused by the dietary patterns with a lack of fruits and vegetables in the daily menu. This theory requires further ecological studies.

\section{CONFLICT OF INTERESTS}

The authors declare no conflict of interests.

\section{REFERENCES}

1. Dessordi R, Navarro MA. Boron action in bone health. Available from: https://oatext. com/Boron-action-in-bone-health.php (Accessed 20th June 2020).

2. Donoiu I, Militaru C, Obleagă $\mathrm{O}$, Hunter JM, Neamţu J, et al. Journal of Trace Elements in Medicine and Biology: Effects of boron-containing compounds on cardiovascular disease risk factors: a review. Journal of Trace Elements in Medicine and Biology. 2018; 50:47-56.

3. Alan, Archivos Latinoamericanos de Nutrición. Ibarra GR, and. Etchevers Barra JD: Will boron be essential for human nutrition? Available from: https://www.alanrevista.org/ediciones/2016/1/ art-10/ (Accessed 20th June 2020).

4. Hunter JM, Nemzer B, Rangavajla N, Biţă A. et al. The Fructoborates: Part of a Family of Naturally Occurring Sugar-Borate Complexes - Biochemistry, Physiology, and Impact on Human Health: a review. Biological Trace Element Research. 2019;188:11-25.

5. Pietrzkowski Z, Phelan M, Keller R, Shu C, Argumedo R, Reyes-Izquierdo T. Short-term efficacy of calcium fructoborate on subjects with knee discomfort: a comparative, double-blind, placebocontrolled clinical study. Available from: https://www.dovepress.com/short-termefficacy-of-calcium-fructoborate-on-subjects- 
with-knee-disc-peer-reviewed-fulltext-article-CIA (Accessed 20th June 2020).

6. Schauss AG. Boron. Available from: http:// www.rejuvemedical.com/wpcontent/uploads/20 12/09/boron.html (Accessed 20th June 2020).

7. Michael ASH. Minimising the Impact of Age and Arthritis-Related Changes on Joint Health and Function. Available from: https://www.Clinical education.org/resources/reviews/minimisingthe-impact-of-age-and-arthritis-related-changeson-joint-health-and-function/ (Accessed 20th June 2020).

8. Pizzorno L. Nothing Boring About Boron - review article. Integrative Medicine. 2015;4(14):35-48.

9. Goldbach et al. Boron in Plant and Animal Nutrition. In: NEWNHAM R.E. How Boron is Being Used in Medical Practice. K1uwer AcademiclPlenum Publishers, New York; 2002.

10. Newnham R. et al. Essentiality of Boron for Healthy Bones and Joints. International Symposium on Health Effects of Boron and Its Compounds, 16-17 September 1992, University of California, Irvine, California. Environ Health Perspectives; 1994.

11. Nielsen FH, Meacham SL. Growing Evidence for Human Health Benefits of Boron. Journal of Evidence-Based Complementary \& Alternative Medicine. 2011;16(3):169-180.

12. Morelli V, Naquin C, Weaver V. Alternative Therapies for Traditional Disease States: Osteoarthritis. Available from: https://www.aafp. org/afp/2003/0115/p339.html (Accessed 20th June 2020).

13. Nielsen F.H. Historical and recent aspects of boron in human and animal health. BORON. 2017; 2(3):153-160.

14. Boron. Journal of Dietary Supplements. 2008;5:1, 62-94. Available from: doi: 10.1080/193 90210802329352 (Accessed 10th March 2021).

15. Kolasinski SL. Boron Supplementation for Low Bone Density and Osteoarthritis. Available from: https://www.reliasmedia.com/articles/118545boron-supplementation-for-low-bone-densityand-osteoarthritis (Accessed 20th June 2020).
16. Hussain SA, Abood SJ, Gorial FI. The adjuvant use of calcium fructoborate and borax with etanercept in patients with rheumatoid arthritis: Pilot study. Journal of Intercultural Ethnopharmacology. 2017;6(1):58-64.

17. Abood SJ, Gorial FI, Hussain SA. Safety of boron supplements in rheumatoid arthritis patients maintained on etanercept treatment. Pharmacie Globale. International Journal of comprehensive pharmacy. 2016;03(02):1-5.

18. Ziad S. Al-Rawiet et al. Serum boron concentration in rheumatoid arthritis: correlation with disease activity, functional class, and rheumatoid factor. Available from: https://www.bibliomed.org/?mno=26288 (Accessed 20th June 2020).

19. Al-Rawi ZS, Gorial FI, Al-Shammary WA, Muhsin F, Al-Naaimi AS, Kareem S. Serum boron concentration in rheumatoid arthritis: correlation with disease activity, functional class, and rheumatoid factor. Journal of Experimental and Integrative Medicine. 2013; 3(1):9-15.

20. Ameye LG, Chee WSS. Osteoarthritis and nutrition. From nutraceuticals to functional foods: a systematic review of the scientific evidence. Available

from: https://arthritisresearch.biomedcentral.com/arti cles/10.1186/ar206 (Accessed 20th June 2020).

21. Al-Rawi ZS et al. Rheumatoid arthritis and many other diseases associated with low Boron - 2012. Available from: https://vitamindwiki.com/ Rheumatoid+arthritis+and+many+other+disea ses+associated+with+low+Boron+\%E2\%80\%93 +2012 (Accessed 20th June 2020).

22. Travers Fracp RL, Rennie GC, Newnham RE. Boron and Arthritis: the Results of a Double-blind Pilot Study. Journal of Nutritional Medicine. 1990;1:127-132.

23. Hughes EJ. Nutritional Protocol for Osteoarthrosis (Degenerative Joint Disease). Available from: https://clinical-nutrition.imedpub.com/nutritio nal-protocol-for-osteoarthrosisdegenerativejoint-disease.php?aid=18718 (Accessed 20th June 2020).

Date of receipt of the manuscript: $29 / 06 / 2021$
Date of acceptance for publication: $30 / 08 / 2021$

Maria-Victoria RACU, ORCID ID: 0000-0002-9203-7892 Ion Romulus SCOREI, ORCID ID: 0000-0001-7157-4288, Web of Science Researcher ID A-9869-20L0 Iurie PINZARU, ORCID ID: 0000-0001-5293-8410 